\title{
Evolution of Beak and Feather Disease Virus across Three Decades of Conservation Intervention for Population Recovery of the Mauritius Parakeet
}

\author{
Deborah J. Fogell ${ }^{1,2} \mathbb{D}^{\mathbb{D}}$, Simon Tollington ${ }^{1,3}{ }^{\mathbb{D}}$, Vikash Tatayah ${ }^{4}$, Sion Henshaw ${ }^{4}$, Houshna Naujeer ${ }^{5}$, Carl Jones ${ }^{6}$, \\ Claire Raisin ${ }^{7}$, Andrew Greenwood ${ }^{8}$ and Jim J. Groombridge ${ }^{1, *(D)}$
}

1 Durrell Institute of Conservation and Ecology, School of Anthropology and Conservation, University of Kent, Canterbury CT2 7NZ, UK; djfogell@outlook.com (D.J.F.); simon.tollington@gmail.com (S.T.)

2 Institute of Zoology, Zoological Society of London, Regents Park, London NW1 4RY, UK

3 School of Animal, Rural and Environmental Sciences, Nottingham Trent University, Brackenhurst, Southwell, Nottinghamshire NG25 0QF, UK

4 Mauritian Wildlife Foundation, Grannum Road, Vacoas 73418, Mauritius; vtatayah@mauritian-wildlife.org (V.T.); shenshaw@mauritian-wildlife.org (S.H.)

5 National Parks and Conservation Service, Ministry of Agro-Industry, Government of Mauritius, Reduit 80835, Mauritius; naujeerhb@gmail.com

6 Durrell Wildlife Conservation Trust, Les Augres Manor, Trinity, Jersey, Channel Islands JE3 5BP, UK; carlgjones@btinternet.com

check for updates

Citation: Fogell, D.J.; Tollington, S.; Tatayah, V.; Henshaw, S.; Naujeer, H.; Jones, C.; Raisin, C.; Greenwood, A.; Groombridge, J.J. Evolution of Beak and Feather Disease Virus across Three Decades of Conservation Intervention for Population Recovery of the Mauritius Parakeet. Diversity 2021, 13, 584. https://doi.org $/ 10.3390 / \mathrm{d} 13110584$

Academic Editors: José L. Tella, Guillermo Blanco and Martina Carrete

Received: 11 October 2021 Accepted: 3 November 2021 Published: 16 November 2021

Publisher's Note: MDPI stays neutral with regard to jurisdictional claims in published maps and institutional affiliations.

Copyright: () 2021 by the authors. Licensee MDPI, Basel, Switzerland. This article is an open access article distributed under the terms and conditions of the Creative Commons Attribution (CC BY) license (https:// creativecommons.org/licenses/by/ $4.0 /)$.
7 North of England Zoological Society, Chester Zoo, Upton-by-Chester, Chester CH2 1EU, UK: c.raisin@chesterzoo.org

$8 \quad$ Wildlife Vets International, Keighley BD21 4NQ, UK; A.Greenwood@izvg.co.uk

* Correspondence: J.Groombridge@kent.ac.uk

\begin{abstract}
Emerging infectious diseases (EIDs) are key contributors to the current global biodiversity crisis. Psittaciformes (parrots) are one of the most vulnerable avian taxa and psittacine beak and feather disease (PBFD) is the most common viral disease in wild parrots. PBFD is caused by the beak and feather disease virus (BFDV), which belongs to the Circoviridae family and comprises a circular, single-stranded DNA genome. BFDV is considered to have spread rapidly across the world and, in 2005, an outbreak of PBFD was documented in the recovering population of the Mauritius parakeet (Alexandrinus eques). The Mauritius parakeet was once the world's rarest parrot and has been successfully recovered through 30 years of intensive conservation management. Molecular surveillance for the prevalence of BFDV was carried out across a 24-year sample archive spanning the period from 1993 to 2017, and DNA sequencing of positive individuals provided an opportunity to assess patterns of phylogenetic and haplotype diversity. Phylogenetic analyses show variation in the extent of viral diversification within the replicase protein (Rep). Timeseries of BFDV prevalence and number of haplotypes reveal that two subsequent waves of infection occurred in 2010/2011 and 2013/2014 following the initial outbreak in 2005. Continued disease surveillance to determine the frequency and intensity of subsequent waves of infection may benefit future translocation/reintroduction planning. The continued growth of the Mauritius parakeet population despite the presence of BFDV bodes well for its long-term persistence.
\end{abstract}

Keywords: BFDV; emerging infectious disease; haplotypes; parrot; PBFD; viral diversification

\section{Introduction}

Emerging infectious diseases (EIDs) are key contributors to the current global biodiversity crisis [1,2]. Although population biologists recognize infectious pathogens as an integral mechanism for evolutionary change within natural populations [3], the emergence of novel pathogens may increase the risk of extinction for vulnerable species and populations [4]. Viruses are responsible for over $40 \%$ of all recently surveyed wildlife EIDs [5,6], and consequently have been highlighted as an important threat to the conservation of 
global biodiversity. The threats from viruses are in part due to their ability to adapt rapidly to novel hosts [7,8], enabling them to become infectious across a wide host range [7].

Psittaciformes (parrots) are one of the most vulnerable avian taxa, with approximately $30 \%$ of all extant species listed as Vulnerable or Threatened by the International Union for Conservation of Nature and more than $75 \%$ of species in population decline [9]. One major threat to parrots is the emergence and global spread of Psittacine Beak and Feather Disease (PBFD), the most common viral disease in wild Psittaciformes [10]. PBFD was first described in the 1970s [11] and is thought to have post-Gondwanan origins due to the paucity of ancestral non-Australian clades and infrequent observations across other regions where parrot endemism is high, such as Africa and South America [12]. It is caused by the Beak and Feather Disease Virus (BFDV), which belongs to the Circoviridae family and comprises a circular, single-stranded DNA genome of approximately 2000 nucleotides [13]. Both its small size and structure make BFDV a relatively simple pathogen for studying molecular variation in the context of disease ecology and drivers of spread [14]. The genome consists of a highly conserved replicase (Rep) $[15,16]$ and a capsid (Cap) protein responsible for viral encapsidation and host-cell penetration [16,17]. BFDV is transmissible horizontally, through contact with contaminated feather dust, surfaces, or objects [18], and vertically, from a female to her offspring [19].

BFDV is thought to have spread rapidly across the world owing to its high environmental persistence and ability to shift between closely related host species [20,21]. All Psittaciformes are considered to be susceptible to infection [14] and to date, BFDV or PBFD has been recorded in a total of 78 species (18 New World and 60 Old World) and five subspecies globally [22]. Small, isolated host populations such as parrot species endemic to islands are considered to be particularly vulnerable to EIDs, as their populations often have low genetic diversity $[23,24]$ and have frequently evolved in the presence of an impoverished pathogen community [23,25]. Island species are also increasingly at risk due to human-facilitated biological invasions and the alteration of an often already limited habitat [26], with the number of bird species introduced to oceanic islands being roughly equal to the number of species extirpated from them [27]. Consequently, island-endemic parrot populations infected with BFDV can provide near-ideal study systems for documenting how this virus evolves in its psittacine host.

The Mauritius parakeet (Alexandrinus eques) was once the world's rarest parrot [16,28], but by 2017 had recovered to approximately 136 known breeding pairs [29]. PBFD was first recorded in the Mauritius parakeet in the early 1990s [30,31] and low viral prevalence was detected in blood samples taken on an ad hoc basis from 1993 to 2004 . However, in the 2005/2006 breeding season, an outbreak of PBFD swept through the population of Mauritius parakeets, coinciding with a viral mutation located in Rep [16]. Since that outbreak, blood samples have been taken from all annually produced offspring. Extracted DNA from each sample has been screened using PCR $[16,32]$ to detect the presence of BFDV and positive samples have been sequenced to distinguish the different viral haplotypes (genetic variants). This process has provided a unique opportunity to characterise the temporal evolution of BFDV in the Mauritius parakeet host population spanning the last three decades before, during, and after the outbreak [16,33].

Here, we assess some of the patterns evident in the BFDV viral haplotypes present in the endemic Mauritius parakeet on Mauritius through phylogenetic and haplotype network analyses. We (i) examine patterns of viral diversification that have occurred in isolation on Mauritius since 1993, (ii) compare the rate of BFDV mutation on Mauritius to that found in other global regions, and (iii) interpret the patterns of BFDV prevalence and viral diversity in a context of multiple outbreak events following the initial outbreak in 2005. Finally, we consider how this EID should be viewed in the context of the future conservation management of the Mauritius parakeet. Our findings provide valuable insights into the evolutionary dynamics of BFDV in a recovering host population of this once critically endangered species, the last remaining endemic parrot of the Mascarene islands [34]. 


\section{Materials and Methods}

\subsection{Mauritius Parakeet Sampling, DNA Extraction, $P C R$, and Sequencing}

Blood samples were taken by the Mauritius parakeet field team from all accessible 45-day-old nestlings produced each breeding season (September to May) since 2005 and opportunistically from post-fledged birds since 1993 as part of ongoing species management. For this study, a total of 1321 samples were screened for BFDV across all breeding seasons from 2009/2010 to 2016/2017 (comprising 639 breeding attempts where at least one fledgling was produced). The resulting DNA sequences of viral haplotypes were added to an existing viral prevalence dataset for the Mauritius parakeet [16], resulting in a dataset spanning 24 years. Additionally, 70 further Mauritius parakeet blood samples were screened from three cohorts of fledglings that were translocated from the Black River Gorges National Park to Vallée de Ferney during the 2014/2015, 2015/2016, and 2016/2017 breeding seasons as part of a conservation translocation programme to establish a Mauritius parakeet population on the east coast of Mauritius. Prior to screening for BFDV, an ammonium acetate DNA extraction method was used to extract both host and viral DNA [35]. In brief, approximately 50 to $100 \mu \mathrm{L}$ of whole blood was digested in $250 \mu \mathrm{L}$ of DIGSOL lysis buffer (20 mM EDTA, $50 \mathrm{mM}$ Tris, $120 \mathrm{mM} \mathrm{NaCl}, 1 \%$ SDS, pH 8.0) with $10 \mu \mathrm{L}$ of $10 \mathrm{mg} / \mathrm{mL}$ proteinase K. Extractions were quantified using a Qubit dsDNA Assay Kit and standardized to approximately $25 \mathrm{ng} / \mu \mathrm{L}$ prior to screening for BFDV using PCR.

Virus-specific PCR primers were then used to determine the presence of viral DNA within that of the host. Screening was carried out through a PCR assay that amplified a $717 \mathrm{bp}$ region of Rep [36]. Reactions comprised $1 \mu \mathrm{L}$ of extracted DNA template, $5 \mu \mathrm{L}$ MyTaq ${ }^{\text {TM }}$ HS Red Mix (Bioline), $0.2 \mu \mathrm{L}$ each of the forward and reverse primers at $10 \mathrm{pmol} / \mu \mathrm{L}$ and were made up to $10 \mu \mathrm{L}$ with double-distilled water. PCR annealing temperature was set to $60^{\circ} \mathrm{C}$ for 30 cycles and products were visualized on a $1.5 \%$ agarose gel. Both a known BFDV-positive Mauritius parakeet sample and a negative control were included in each PCR batch. All positive PCR products were sequenced using forward and reverse sequencing reactions (Macrogen Europe, Amsterdam, The Netherlands). All sequences obtained from Mauritius parakeet hosts between 2009 and 2017 have been deposited in GenBank (KT753406-KT753526, MZ673091-MZ673140).

\subsection{BFDV Phylogeny and Haplotype Network}

Geneious 8.1.7 [37] DNA editing software was used to align and edit forward and reverse sequence reads and to produce a consensus sequence for each positive sample. Rep was chosen for analysis because a previous study identified a selective mutation in this gene as being the most likely cause for the initial outbreak of PBFD observed on Mauritius in 2005 [16]. For phylogenetic reconstruction, the programme jModelTest 2.1.7 [38] was used to infer the best-fit nucleotide substitution model. A transition model with gammadistributed rate variation and a proportion of invariable sites $(G T R+I+G)$ was favoured. We constructed a maximum likelihood (ML) phylogenetic tree using RAxML version 8 [39], which applies a gamma substitution model and a rapid bootstrapping (RBS) heuristic procedure [40]. We collapsed branches with $<50 \%$ bootstrap support using TreeGraph 2 [41] and edited and annotated the final tree in FigTree version 1.4.4 [42].

Network 10.2.0.0 [43] was used to construct a median-joining nucleotide haplotype network for Rep sequences to analyse patterns in clustering and diversity both temporally and spatially. We used DNAsp 6.12.03 [44] to examine whether the Mauritius BFDV population had experienced demographic changes (significant population expansion) over the assessed period. Departures from mutation-drift equilibrium were tested using Fu's $F_{S}$ statistic [45], where a negative value would be indicative of diversification and a positive value would be reflective of a recent population bottleneck.

\section{Results}

The blood samples that amplified a PCR product for BFDV yielded edited sequences of $462 \mathrm{bp}$ of the Rep gene. Since the first observation of BFDV in Mauritius parakeets in 
the 1993/1994 breeding season, our data indicate that this section of the Rep gene has diverged into 63 observed haplotypes. Of these, 49 haplotypes were detected in single host individuals, whereas seven haplotypes occurred in more than five individuals and persisted over multiple breeding seasons. The maximum likelihood phylogeny given in Figure 1 shows an 'outbreak cluster' of haplotypes that comprises haplotypes sampled during the 2005/2006 outbreak year as well as a mixture of phylogenetically similar haplotypes sampled from across subsequent years, particularly from 2008/2009 and 2010/2011. In contrast, several other large clusters of haplotypes appear to comprise haplotypes that are sampled from just one or two years; for example, 'cluster A' comprises haplotypes almost entirely from 2006/2007 and 2014/2015 years, 'cluster B' comprises predominantly haplotypes from 2013/2014, and 'cluster C' comprises haplotypes entirely from 2015/2016 and 2016/2017. Those sequences obtained from the 2015/2016 and 2016/2017 breeding seasons are the only ones to not have any dispersal throughout the rest of the phylogeny.

Figure 2 shows the changes in BFDV prevalence since the initial outbreak in 2005 against a backdrop of increasing numbers of host-breeding pairs as the host population has continued to recover from its initial low population size as a consequence of intensive conservation management. The changes in BFDV prevalence indicate that the parakeet host population has experienced at least two subsequent 'waves' of BFDV infection; in 2010/2011 (39.4\% BFDV prevalence) and in 2013/2014 (41.3\% BFDV prevalence) that were equal to or larger than the initial 2005 outbreak, interspersed with periods of low infection. The haplotype network shown in Figure 3 indicates at least three clusters of the most frequently occurring BFDV haplotypes (Figure 3a), with each one of the three most dominant haplotypes being those corresponding to the initial outbreak and the second and third waves of BFDV infection (Figure 3b). The starburst pattern present within the haplotype network is indicative of significant demographic expansion and diversification within the host population since 1993, and is supported by the Fu's F test statistic [45] $(-33.30, p<0.001, \mathrm{k}=4.46, \mathrm{~h}=0.85 \pm 0.00, \pi=0.01 \pm 0.01)$.

There has been a large variation in the number of haplotypes present across breeding seasons, with the largest number seen in the 2010/2011 season $(n=20)$ and the fewest seen in 2006/2007 ( $n=1$ ) (Figure $3 b$ ). We found no geographical/spatial separation of haplotypes and sequences from host individuals in all subpopulations, including captive Mauritius parakeets in the Gerald Durrell Endemic Wildlife Sanctuary (GDEWS) and the newly established subpopulation at Vallée de Ferney, were dispersed throughout the network. A pattern of haplotype dominance was observed across the seasons where a single haplotype comprising the majority of sequences from the initial outbreak in 2005 persisted until 2010/2011. A single base-pair change separates this haplotype from the subsequent dominant haplotype that has persisted from 2011/2012 to the most recently assessed 2016/2017 breeding season (Figure 3a). Although there was a third haplotype group that occurred from $2004 / 2005$, this was only detected at a lower frequency in the Mauritius parakeet population until 2010/2011 and has not been detected since. 


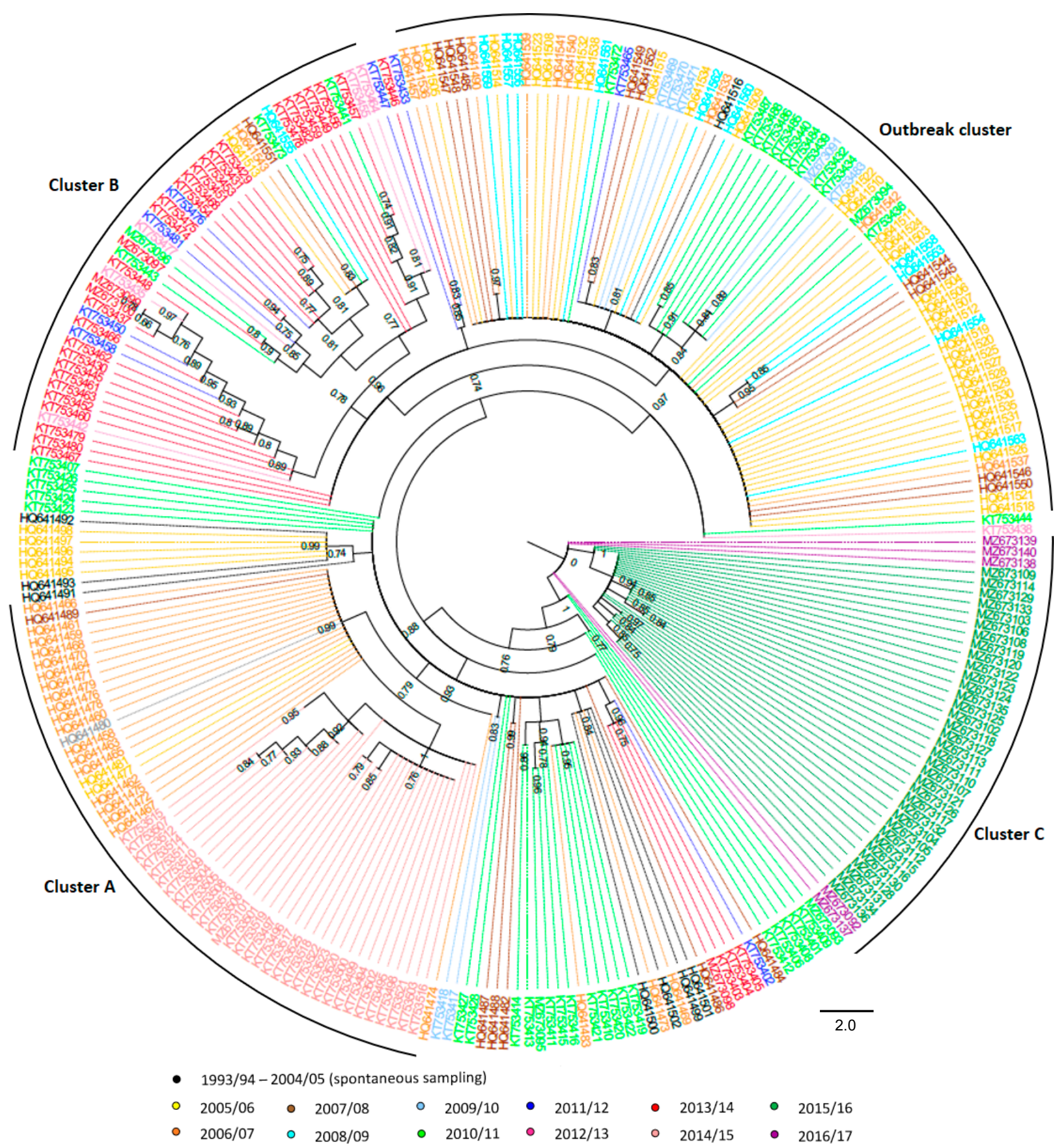

Figure 1. Maximum likelihood phylogenetic tree denoting relationships between BFDV Rep sequences in Mauritius, where branches with $<50 \%$ branch support have been collapsed. Branches are coloured based on the year of sampling as denoted in the key. 


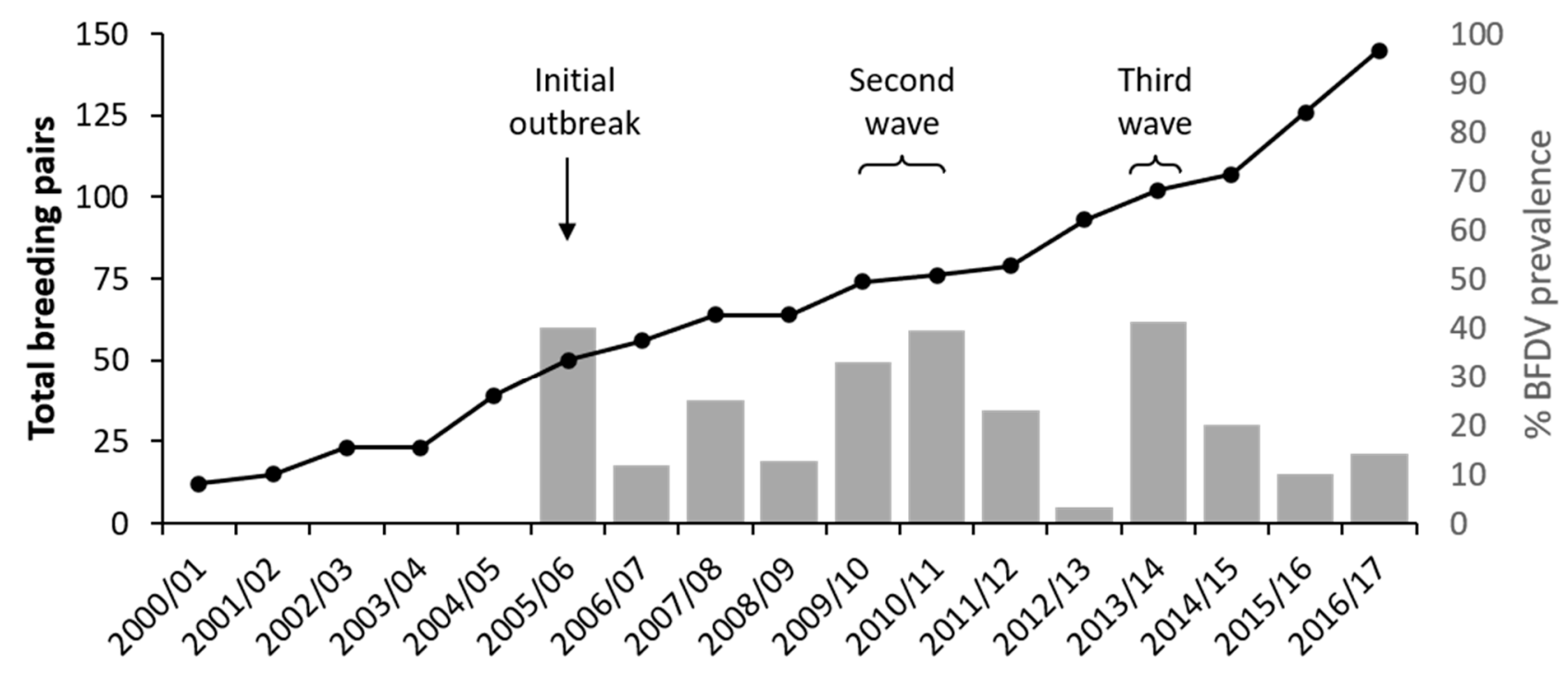

\section{Breeding Season}

Figure 2. The total number of Mauritius parakeet breeding pairs recorded between 2000 and 2017 (black line) plotted with the percentage BFDV prevalence detected in offspring produced in each breeding season since systematic sampling began in 2005 (grey bars).

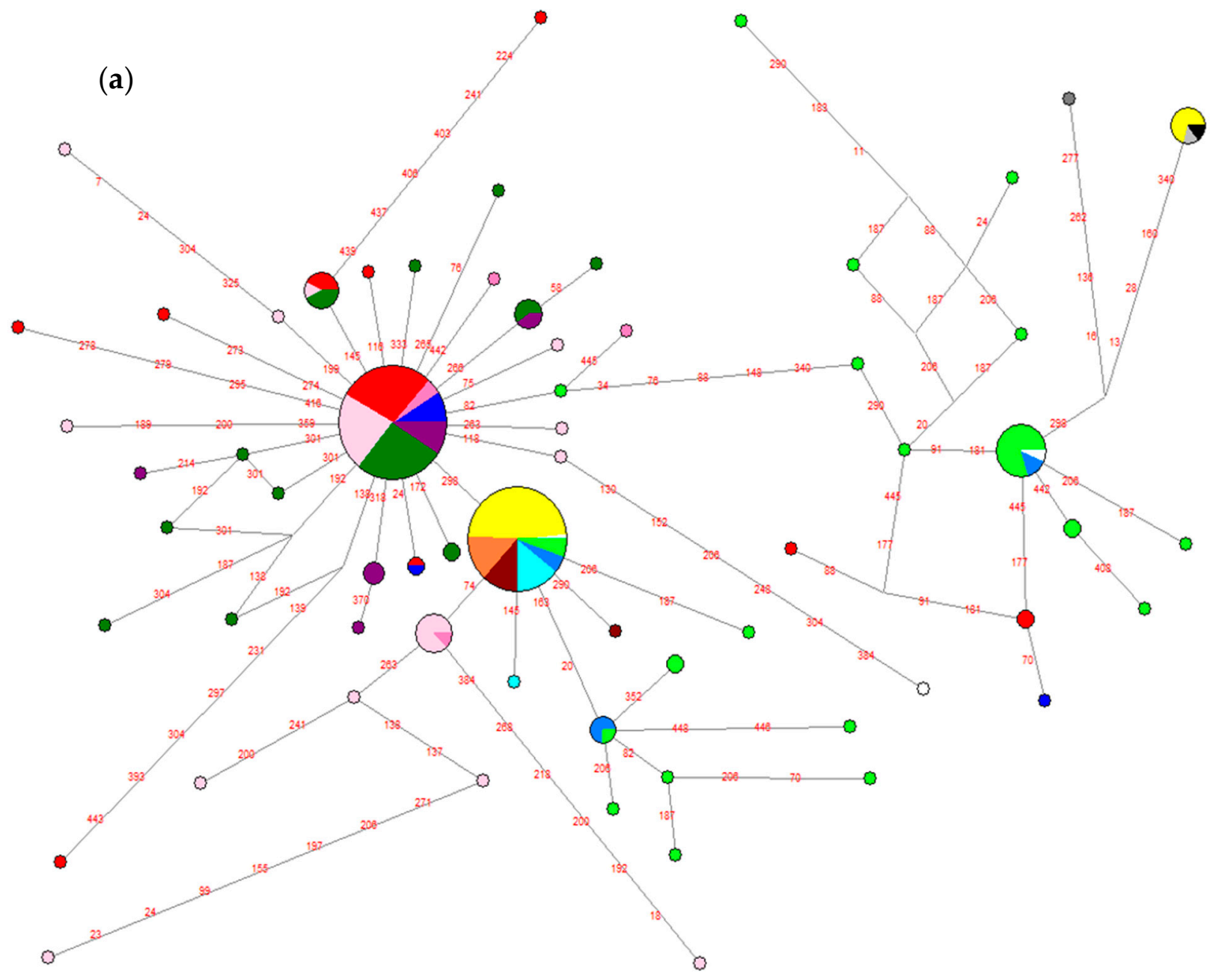

Figure 3. Cont. 
(b)

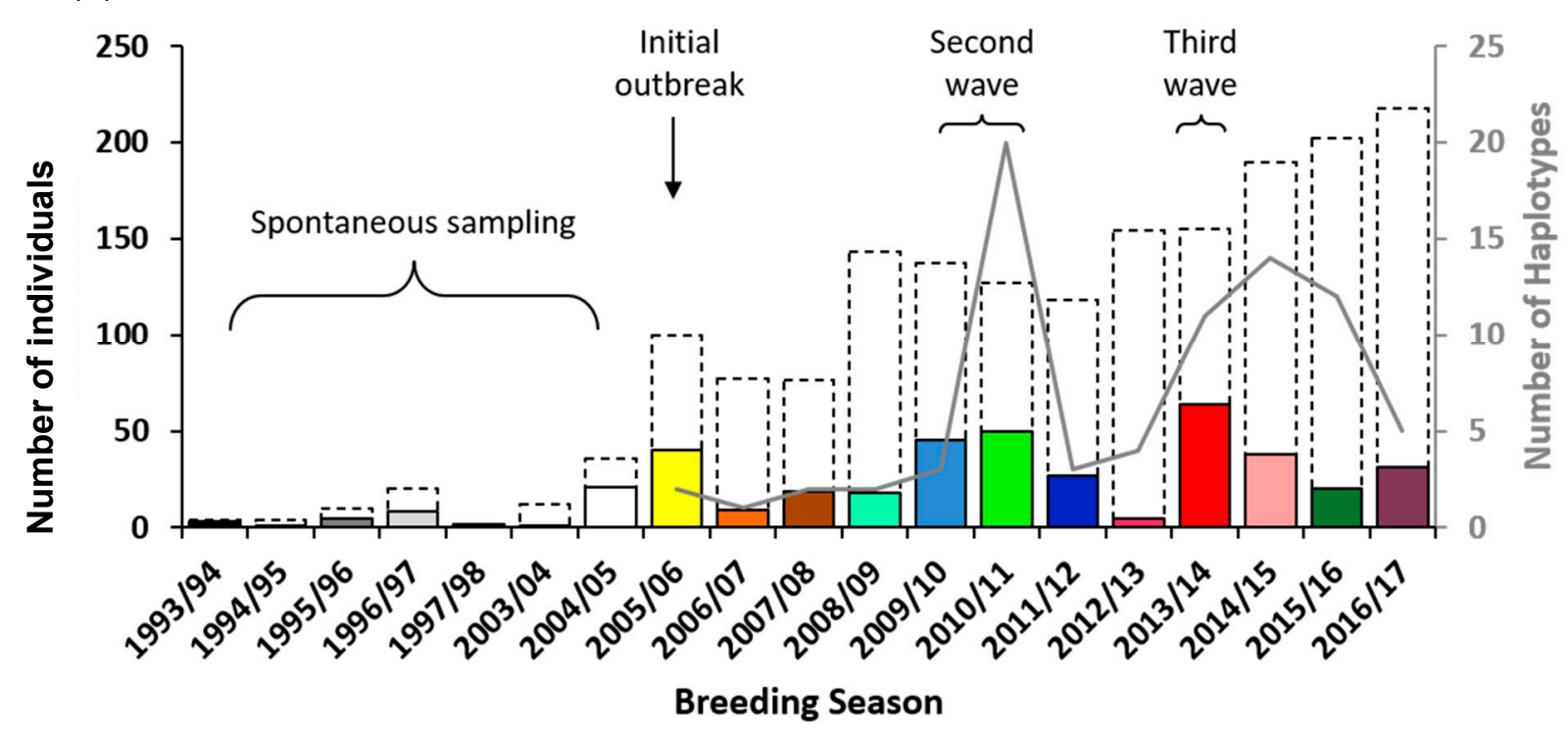

Figure 3. (a, top) Haplotype network displaying the diversity and evolution of BFDV Rep haplotypes in Mauritius parakeet hosts. The size of each circle is proportional to the number of individuals sharing that viral haplotype and the length of the lines between circles are proportional to the number of base pair changes between each haplotype. (b, bottom) Number of individuals screened (dashed bars), viral prevalence (solid bars), and number of haplotypes (grey line) detected from 1993 to 2017. Color codes in 3a refer to the sampling year shown in 3b. The screening dataset from 2005 to 2017 comprises a systematic sampling of fledglings.

\section{Discussion}

Pathogen persistence in large populations is generally regulated by host population size and density, whereas pathogen establishment among small populations is much more likely to be influenced by stochastic factors [3]. Host-parasite relationships are often disrupted in threatened species, which can result in the local elimination of endemic diseases owing to reduced size and increased fragmentation of host species beyond a threshold required to maintain viral transmission [46]. As a result of a very successful conservation initiative, the Mauritius parakeet population has grown and has become less fragmented and, as a consequence, it is probable that pre-bottleneck host-parasite dynamics have been restored to some extent. Furthermore, there has been a rapid increase in the highly invasive rose-ringed parakeet (Alexandrinus krameri) population on the island [16], which potentially acts as a reservoir host for BFDV infection and transmission.

The strain of BFDV present within the Mauritius parakeet population has rapidly diversified over the last three decades, with two subsequent waves of high prevalence since the initial outbreak in 2005 . The ability of a pathogen to establish in a host population has a direct relationship with its transmission efficiency and an inverse relationship with its virulence [3,46]. Although BFDV has been found to be widely infectious [47] and PBFD is frequently fatal in immature birds up to three years of age [19], infected adults commonly recover from severe clinical presentation of the disease, which usually lasts only for a number of months [48]. These attributes of BFDV appear to have allowed it to become highly prevalent in the Mauritius parakeet population whereas host numbers have continued to increase [33]. A prevalence of BFDV among Mauritius parakeets nestlings of $41.3 \%$ in 2013/2014 is one of the highest among wild parrot populations to our knowledge [22].

\subsection{Multiple Waves of BFDV Infection Following Initial Outbreak}

Our screening for BFDV across three decades has identified two additional 'waves' of BFDV infection in the Mauritius parakeet population. Such peaks and troughs of infection are a common signature of pathogen populations and may be an indication of the host-pathogen dynamics between the host's immune system and the ability of 
the virus to mutate. The timing of the outbreak in 2005 and subsequent two waves of infection in 2010/2011 and 2013/2014 suggests a periodicity of between 3 and 5 years. This corresponds to the estimated generation time for Mauritius parakeets of 4 years, as determined through observations of the species in the wild [49], where generation time was defined as the average age of reproduction and is also the average time from reproduction in one generation to reproduction in the next generation [50]. As there has been substantial genetic homogenisation of the Mauritius parakeet population due to conservation management for recovery [51], this may have influenced the host-pathogen coevolution cycle [52], which could be an avenue for future research with the potential opportunities available through whole-genome sequencing. Future screening for BFDV, and identification of further waves of infection, will determine whether the regularity at which they occur stabilises and whether host population size has an influence on their frequency and intensity. If the periodicity of waves of infection remains relatively stable, then this knowledge may provide valuable insight for future conservation management of the Mauritius parakeet population. Although it is still important to note that the high prevalence of infection does not necessitate high pathogenicity $[47,53]$, these considerations could assist in timing planned future translocation/reintroduction initiatives to occur between waves of infection.

\subsection{BFDV in the Context of Ongoing Conservation Management}

During the intensive management and recovery of this host population, interventions such as brood manipulation, captive breeding, and reintroduction were undertaken to help rapidly increase the number of parakeets [51,54]. The Mauritian Wildlife Foundation's parakeet field team has attempted to reduce or eliminate any potential human-mediated transmission of BFDV with a rigorous biosecurity and hygiene protocol since 2005 [32]. However, despite these protocols, the recent translocation of parakeets to Le Vallée de Ferney on Mauritius to initiate a new subpopulation also included the transfer of BFDV to the east coast. The unavoidable regular movement of vehicles, equipment, and field staff between localities for ongoing species management is the most likely reason for this movement of viral populations, which is evident in the lack of within-subpopulation haplotype clustering, despite their geographical separation. In addition to this, some translocated individuals are known to have relocated back to the Black River Gorges National Park (S Henshaw, Pers. Obs.), indicating that these non-breeding sub-adults may now also facilitate the transmission of BFDV between subpopulations.

Although our haplotype network generated for the strain of BFDV present on Mauritius provides a window into the viral population dynamics and diversification, it is unlikely to represent all variants present on the island given that it is based on a fragment of the Rep gene rather than the full BFDV genome. The ability for multiple BFDV infections to persist within a single host, along with its high rate of mutation, allows for the rapid evolution of novel BFDV variants through recombination [54]. Indeed, we have detected some instances of multiple infections in this study system, although from limited screening. Currently, there only appears to be a single strain of BFDV present in Mauritius, and this is shared between both the native and introduced populations [47]. However, if novel BFDV variants are introduced to the Mauritius parakeet population through an accidental leak from captive pet parrot species (as is plausibly the case with the introduction of roseringed parakeets to the island [16]), such an event may alter the virus' pathogenicity and subsequently increase the threat imposed by infection $[55,56]$.

Despite the continued presence (and at times high prevalence) of BFDV in the Mauritius parakeet, the population size of this once critically endangered species continues to grow (Figure 2). The species was down-listed by the IUCN to Endangered in 2007 and to Vulnerable in 2019. This positive population trajectory in the face of an EID stands as an encouraging example that runs counter to expectations for bottlenecked islandendemic species which are often suspected to be immunologically naïve and genetically impoverished, and consequently are expected to respond poorly to the challenges of EIDs. 
Author Contributions: Conceptualization and methodology, D.J.F., S.T., A.G. and J.J.G.; validation, S.H., C.J., V.T., A.G. and H.N.; formal analysis, D.J.F. and S.T.; sample collection, S.H., S.T., C.R., C.J., V.T., A.G. and H.N.; data curation, D.J.F., S.T., C.R. and J.J.G.; writing-original draft preparation, D.J.F., S.T. and J.J.G.; writing-review and editing, All authors; visualization, D.J.F.; funding acquisition, D.J.F., S.T. and J.J.G. All authors have read and agreed to the published version of the manuscript.

Funding: This work was supported by funds contributed to D.J.F. by the National Environmental Research Council (DTP grant number NE/L002582/1), African Bird Club, the Genetics Society, and the Durrell Institute of Conservation and Ecology. The research was also facilitated by a British Ecological Society Small Research Grant (5163-6205) awarded to S.T.

Institutional Review Board Statement: This research received ethical approval from the Research Ethics Committee of the School of Anthropology and Conservation at the University of Kent on $28^{\text {th }}$ October 2015 (the UK does not have a national registration system for university research ethics committees). Sampling was undertaken in collaboration with and with permission from local wildlife authorities, conservation nongovernmental, and research organizations.

Data Availability Statement: This statement confirms that, should the manuscript be accepted, then data supporting the results will be archived in the Kent Academic Repository.

Acknowledgments: We thank the other MWF Mauritius parakeet project volunteers and staff who contributed to sample collection and nest site management, and NPCS for permission to work within the national park.

Conflicts of Interest: The authors declare no conflict of interest. The funders had no role in the design of the study; in the collection, analyses, or interpretation of data; in the writing of the manuscript, or in the decision to publish the results.

\section{References}

1. Brooks, D.R.; Ferrao, A.L. The historical biogeography of co-evolution: Emerging infectious diseases are evolutionary accidents waiting to happen. J. Biogeogr. 2005, 32, 1291-1299. [CrossRef]

2. Yap, T.A.; Koo, M.S.; Ambrose, R.F.; Wake, D.B.; Vredenburg, V.T. Averting a North American biodiversity crisis. Science 2015, 349, 481-482. [CrossRef]

3. Lyles, A.M.; Dobson, A.P. Infectious disease and intensive management: Population dynamics, threatened hosts, and their parasites. J. Zoo Wildl. Med. 1993, 24, 315-326.

4. Lips, K.R.; Brem, F.; Brenes, R.; Reeve, J.D.; Alford, R.A.; Voyles, J.; Carey, C.; Livo, L.; Pessier, A.P.; Collins, J.P. Emerging infectious disease and the loss of biodiversity in a neotropical amphibian community. Proc. Natl. Acad. Sci. USA 2006, 103, 3165-3170. [CrossRef]

5. Dobson, A.; Foufopoulos, J. Emerging infectious pathogens of wildlife. Philos. Trans. R. Soc. Lond. B. Biol. Sci. 2001, 356, 1001-1012. [CrossRef] [PubMed]

6. Tompkins, D.M.; Carver, S.; Jones, M.E.; Krkošek, M.; Skerratt, L.F. Emerging infectious diseases of wildlife: A critical perspective. Trends Parasitol. 2015, 31, 149-159. [CrossRef] [PubMed]

7. Altizer, S.; Harvell, D.; Friedle, E. Rapid evolutionary dynamics and disease threats to biodiversity. Trends Ecol. Evol. 2003, 18, 589-596. [CrossRef]

8. Jones, K.E.; Patel, N.G.; Levy, M.A.; Storeygard, A.; Balk, D.; Gittleman, J.L.; Daszak, P. Global trends in emerging infectious diseases. Nature 2008, 451, 990-993. [CrossRef]

9. IUCN. The IUCN Red List of Threatened Species. Version 2020-3. Available online: http:/ / www.iucnredlist.org/ (accessed on 1 August 2021).

10. Khalesi, B.; Bonne, N.; Stewart, M.; Sharp, M.; Raidal, S. A comparison of haemagglutination, haemagglutination inhibition and PCR for the detection of Psittacine beak and feather disease virus infection and a comparison of isolates obtained from loriids. J. Gen. Virol. 2005, 86, 3039-3046. [CrossRef] [PubMed]

11. Pass, D.A.; Perry, R.A. The pathology of Psittacine beak and feather disease. Aust. Vet. J. 1984, 61, 69-74. [CrossRef]

12. Raidal, S.R.; Sarker, S.; Peters, A. Review of Psittacine beak and feather disease and its effect on Australian endangered species. Aust. Vet. J. 2015, 93, 466-470. [CrossRef]

13. Ritchie, B.W.; Niagro, F.D.; Lukert, P.D.; Steffens, W.L., III; Latimer, K.S. Characterization of a new virus from cockatoos with psittacine beak and feather disease. Virology 1989, 171, 83-88. [CrossRef]

14. Sarker, S.; Ghorashi, S.A.; Forwood, J.K.; Bent, S.J.; Peters, A.; Raidal, S.R. Phylogeny of beak and feather disease virus in cockatoos demonstrates host generalism and multiple-variant infections within Psittaciformes. Virology 2014, 460, 72-82. [CrossRef]

15. Kondiah, K.; Albertyn, J.; Bragg, R.R. Genetic diversity of the rep gene of Beak and feather disease virus in South Africa. Arch Virol. 2006, 151, 2539-2545. [CrossRef] [PubMed] 
16. Kundu, S.; Faulkes, C.G.; Greenwood, A.G.; Jones, C.G.; Kaiser, P.; Lyne, O.D.; Black, S.A.; Chowrimootoo, A.; Groombridge, J.J. Tracking viral evolution during a disease outbreak: The rapid and complete selective sweep of a Circovirus in the endangered Echo parakeet. J. Virol. 2012, 86, 5221-5229. [CrossRef]

17. Heath, L.; Martin, D.P.; Warburton, L.; Perrin, M.; Horsfield, W.; Kingsley, C.; Rybicki, E.P.; Williamson, A.-L. Evidence of unique genotypes of Beak and feather disease virus in Southern Africa. J. Virol. 2004, 78, 9277-9284. [CrossRef] [PubMed]

18. Ritchie, P.A.; Anderson, I.L.; Lambert, D.M. Evidence for specificity of Psittacine beak and feather disease viruses among avian hosts. Virology 2003, 306, 109-115. [CrossRef]

19. Ritchie, B.W.; Niagro, F.D.; Lukert, P.D.; Latimer, K.S.; Steffens III, W.L.; Pritchard, N. A review of Psittacine beak and feather disease: Characteristics of the PBFD virus. J. Assoc. Avian Vet. 1989, 3, 143-150. [CrossRef]

20. Peters, A.; Patterson, E.I.; Baker, B.G.B.; Holdsworth, M.; Sarker, S.; Ghorashi, S.A.; Raidal, S.R. Evidence of Psittacine beak and feather disease virus spillover into wild critically endangered Orange-bellied parrots (Neophema chrysogaster). J. Wildl. Dis. 2014, 50, 288-296. [CrossRef]

21. Sarker, S.; Patterson, E.I.; Peters, A.; Baker, G.B.; Forwood, J.K.; Ghorashi, S.A.; Holdsworth, M.; Baker, R.; Murray, N.; Raidal, S.R. Mutability dynamics of an emergent single stranded DNA virus in a naïve host. PLoS ONE 2014, 9, e8537. [CrossRef]

22. Fogell, D.J.; Martin, R.O.; Groombridge, J.J. Beak and feather disease virus in wild and captive parrots: An analysis of geographic and taxonomic distribution and methodological trends. Arch. Virol. 2016, 161, 2059-2074. [CrossRef] [PubMed]

23. Wikelski, M.; Foufopoulos, J.; Vargas, H.; Snell, H. Galápagos Birds and Diseases: Invasive Pathogens as Threats for Island Species. Ecol. Soc. 2004, 9, 5. [CrossRef]

24. Trinkel, M.; Cooper, D.; Packer, C.; Slotow, R. Inbreeding depression increases susceptibility to bovine tuberculosis in lions: An experimental test using an inbred-outbred contrast through translocation. J. Wildl. Dis. 2011, 47, 494-500. [CrossRef] [PubMed]

25. Spurgin, L.G.; Illera, J.C.; Padilla, D.P.; Richardson, D.S. Biogeographical patterns and co-occurrence of pathogenic infection across island populations of Berthelot's pipit (Anthus berthelotii). Oecologia 2012, 168, 691-701. [CrossRef]

26. Russell, J.C.; Kueffer, C. Island Biodiversity in the Anthropocene. Annu. Rev. Environ. Resour. 2019, 44, 31-60. [CrossRef]

27. Sax, D.F.; Gaines, S.D.; Brown, J.H. Species invasions exceed extinctions on islands worldwide: A comparative study of plants and birds. Am. Nat. 2002, 160, 766-783. [CrossRef] [PubMed]

28. Jones, C.G. The larger land-birds of Mauritius. In Studies of Mascarene Island Birds; Diamond, A.W., Ed.; Cambridge University Press: Cambridge, UK, 1987; pp. 208-300.

29. Henshaw, S.; Blackwell, L.; Yeung Shi Chung, C.; Bielsa, M.; Bertille, H. Mauritian Wildlife Foundation: Echo Parakeet (Psittacula eques) Management Report 2017/2018; Mauritian Wildlife Foundation: Vacoas, Mauritius, 2018.

30. Lovegrove, T.G.; Nieuwland, A.B.; Green, S. Interim Report on the Echo Parakeet Conservation Project; Mauritian Wildlife Foundation: Vacoas, Mauritius, 1995.

31. Greenwood, A.G. Veterinary support for in situ avian conservation programmes. Bird Conserv. Int. 1996, 6, 285-292. [CrossRef]

32. Fogell, D.J.; Groombridge, J.J.; Tollington, S.; Canessa, S.; Henshaw, S.; Zuel, N.; Jones, C.G.; Greenwood, A.; Ewen, J.G. Hygiene and biosecurity protocols reduce infection prevalence but do not improve fledging success in an endangered parrot. Sci. Rep. 2019, 9, 1-10. [CrossRef] [PubMed]

33. Tollington, S.; Greenwood, A.; Jones, C.G.; Hoeck, P.; Chowrimootoo, A.; Smith, D.; Richards, H.; Tatayah, V.; Groombridge, J.J. Detailed monitoring of a small but recovering population reveals sublethal effects of disease and unexpected interactions with supplemental feeding. J. Anim. Ecol. 2015, 84, 969-977. [CrossRef]

34. Hume, J.P. Reappraisal of the Parrots (Aves: Psittacidae) from the Mascarene Islands, with Comments on Their Ecology, Morphology, and Affinities; Magnolia Press: Auckland, New Zealand, 2007; ISBN 1175-5326.

35. Bruford, M.W.; Hanotte, O.; Brookfield, J.F.Y.; Burke, T. Single-locus and multilocus DNA fingerprinting. In Molecular Genetic Analysis of Populations: A Practical Approach; Hoelzel, A.R., Ed.; IRL Press: Oxford, UK, 1998; pp. 287-336.

36. Ypelaar, I.; Bassami, M.R.; Wilcox, G.E.; Raidal, S.R. A universal polymerase chain reaction for the detection of Psittacine beak and feather disease virus. Vet. Microbiol. 1999, 68, 141-148. [CrossRef]

37. Kearse, M.; Moir, R.; Wilson, A.; Stones-Havas, S.; Cheung, M.; Sturrock, S.; Buxton, S.; Cooper, A.; Markowitz, S.; Duran, C.; et al. Geneious Basic: An integrated and extendable desktop software platform for the organization and analysis of sequence data. Bioinformatics 2012, 28, 1647-1649. [CrossRef] [PubMed]

38. Posada, D. jModelTest: Phylogenetic model averaging. Mol. Biol. Evol. 2008, 25, 1253-1256. [CrossRef]

39. Stamatakis, A. RAxML version 8: A tool for phylogenetic analysis and post-analysis of large phylogenies. Bioinformatics 2014, 30, 1312-1313. [CrossRef] [PubMed]

40. Stamatakis, A.; Hoover, P.; Rougemont, J. A rapid bootstrap algorithm for the RAxML web servers. Syst. Biol. 2008, 57, 758-771. [CrossRef] [PubMed]

41. Stöver, B.C.; Müller, K.F. TreeGraph 2: Combining and visualizing evidence from different phylogenetic analyses. BMC Bioinform. 2010, 11, 7. [CrossRef]

42. Rambaut, A. FigTree v1.4.2. Available online: http://tree.bio.ed.ac.uk/software/figtree/ (accessed on 17 July 2015).

43. Fluxus Technology Ltd Network 10.2.0.0. Available online: http://www.fluxus-engineering.com/netwinfo.htm (accessed on 1 August 2021).

44. Rozas, J.; Ferrer-Mata, A.; Sánchez-DelBarrio, J.C.; Guirao-Rico, S.; Librado, P.; Ramos-Onsins, S.; Sánchez-Gracia, A. DNA Sequence Polymorphism v 6.12.03. 2018. Available online: http:/ / www.ub.edu/dnasp/ (accessed on 23 May 2021). 
45. Fu, Y.X.; Li, W.H. Statistical tests of neutrality of mutations. Genetics 1993, 133, 693-709. [CrossRef] [PubMed]

46. Easterday, W.R. The first step in the success or failure of emerging pathogens. Proc. Natl. Acad. Sci. USA 2020, 117, $29271-29273$. [CrossRef]

47. Fogell, D.J.; Martin, R.O.; Bunbury, N.; Lawson, B.; Sells, J.; McKeand, A.M.; Tatayah, V.; Trung, C.T.; Groombridge, J.J. Trade and conservation implications of new Beak and feather disease virus detection in native and introduced parrots. Conserv. Biol. 2018, 32, 1325-1335. [CrossRef]

48. Todd, D. Circoviruses: Immunosuppressive threats to avian species: A review. Avian Pathol. 2000, 29, 373-394. [CrossRef]

49. Raisin, C. Conservation Genetics of the Mauritius Parakeet. Ph.D. Thesis, University of Kent, Kent, UK, 2010.

50. Lacy, R.C.; Ballou, J.D.; Pollak, J.P. PMx: Software package for demographic and genetic analysis and management of pedigreed populations. Methods Ecol. Evol. 2012, 3, 433-437. [CrossRef]

51. Raisin, C.; Frantz, A.C.; Kundu, S.; Greenwood, A.G.; Jones, C.G.; Zuel, N.; Groombridge, J.J. Genetic consequences of intensive conservation management for the Mauritius parakeet. Conserv. Genet. 2012, 13, 707-715. [CrossRef]

52. Duxbury, E.M.L.; Day, J.P.; Vespasiani, D.M.; Thüringer, Y.; Tolosana, I.; Smith, S.C.L.; Tagliaferri, L.; Kamacioglu, A.; Lindsley, I.; Love, L.; et al. Host-pathogen coevolution increases genetic variation in susceptibility to infection. Elife 2019, 8, e46440. [CrossRef] [PubMed]

53. McCallum, H.; Dobson, A. Disease, habitat fragmentation and conservation. Hungarian Q. 2008, 49, 2041-2049. [CrossRef]

54. Tatayah, R.V.V.; Malham, J.; Haverson, P.; Van de Wetering, J. Design and provision of nest boxes for echo parakeets Psittacula eques in Black River Gorges National Park, Mauritius. Conserv. Evid. 2007, 4, 16-19.

55. Julian, L.; Piasecki, T.; Chrzastek, K.; Walters, M.; Muhire, B.; Harkins, G.W.; Martin, D.P.; Varsani, A. Extensive recombination detected among Beak and feather disease virus isolates from breeding facilities in Poland. J. Gen. Virol. 2013, 94, 1086-1095. [CrossRef]

56. Jackson, B.; Varsani, A.; Holyoake, C.; Jakob-Hoff, R.; Robertson, I.; McInnes, K.; Empson, R.; Gray, R.; Nakagawa, K.; Warren, K. Emerging infectious disease or evidence of endemicity? A multi-season study of Beak and feather disease virus in wild Red-crowned parakeets (Cyanoramphus novaezelandiae). Arch. Virol. 2015, 160, 2283-2292. [CrossRef] [PubMed] 